CIRR XXI (72) 2015, 107-137

ISSN 1848-5782

UDC 06 1. 1EU:327.391497.4:497.51

DOI 10.1515/cirr-2015-0004

\title{
Political Criteria vs. Political Conditionality: Comparative analysis of Slovenian and Croatian European Union accession processes
}

Ana Bojinović Fenko, Ana Urlić

\section{Abstract}

This study analyses the differences in content and procedure in the application of political criteria and political conditionality in the EU accession processes of Slovenia and Croatia. The article ascertains that with regard to substance, the Commission and EU member states did apply political criteria more extensively and meticulously to Croatia in comparison to Slovenia, but mainly due to the difference in the states' initial assessment of preparedness for EU membership and the application of the principle of own merits. Empirical results, however, show that the differences in political conditionality did not only stem from Croatia's post-conflict conditions, but also from the EU's experience of the 2004 and 2007 enlargements and the concern about the EU's absorption capacity. As for the accession process procedure, the latter has increasingly empowered the Commission rather than EU member states, which bears relevance for future (Western Balkans) enlargements.

KEY WORDS:

EU accession process, political accession criteria, political conditionality, Croatia, Slovenia. 


\section{Introduction}

In their attempt to theorize EU enlargement, Schimmelfennig and Sedelmeier (2002) clustered together EU enlargement studies more than a decade ago by whether they deal with individual member states' enlargement politics or with EU enlargement politics. They showed that EU enlargement studies had focused predominantly on the enlargement from the perspective of the EU itself (considering substance) or dealt with case studies and circumstances of individual member states' paths to the EU. Unfortunately, researchers have since still not given much attention to the development of a more micro aspect, i.e. the EU accession process from the perspective of applicant states, let alone offered comparative analyses. This is duly noted by Noutcheva (2012, Chapters 4 and 5), who studies EU enlargement as a Europeanization process and delineates between the policy of EU conditionality (the substance of accession conditions) and the politics of EU conditionality (the procedure in the accession process).

The Treaty on European Union (TEU) refers to these two aspects of EU enlargement in Article 49. The substance of the conditions to be met by the applicant state reads: "Any European State which respects the values referred to in Article 2 and is committed to promoting them /.../ The conditions of eligibility agreed upon by the European Council shall be taken into account." The procedure to be followed in the conditions' implementation and for the accession to enter into force is described as: "The applicant State shall address its application to the Council, which shall act unanimously after consulting the Commission and after receiving the consent of the European Parliament, which shall act by a majority of its component members. /.../ The conditions of admission /.../ shall be the subject of an agreement between the Member States and the applicant State. This agreement shall be submitted for ratification by all the contracting States in accordance with their respective constitutional requirements" (TEU, Art. 49).

As for the substance of accession criteria, due to the European Commission's (also Commission or EC) assessment of the nature of Central and Eastern European Countries' (CEECs) necessary adjustments 
from previously communist political and socialist economic systems to EU standards, the Copenhagen and Madrid European Councils formulated in 1993 and 1995, respectively, the wordings of more precise conditions to be fulfilled by applicant states. The conditions were set as: a) political criteria (stable institutions that guarantee democracy, the rule of law, human rights and respect for and protection of minorities), b) economic criteria (a functioning market economy, as well as the ability to cope with the pressure of competition and the market forces at work inside the Union) c) the ability to assume the obligations of membership, in particular adherence to the objectives of political, economic and monetary union (European Council, 1993) and d) administrative criterion in the sense that accession countries had to provide sufficient legal and administrative capacity in order to incorporate the acquis communautaire (European Council, 1995). This article focuses on the application of political criteria as the EU legal framework on human rights has been in intensive development also independently of the enlargement policy' and also due to the fact that the transition of political system to achieve performance of democratic, stable institutions entails essential preconditions for successfully meeting other criteria, most evidently the administrative criterion and ability to assume obligations of membership.

Regarding the procedure, the above primary legislation describes the first and the final phase (application and ratification) of the accession process as being dominated by EU member states (and with the consent of the European Parliament) but does not refer to the details of its second phase - the negotiations. The latter is dominated by the Commission, which does not act only as an opinion-maker in the beginning of the accession process (when the assessment of preparedness of an applicant state is provided) but as the central body for administration and content during the negotiation process (Barnes and Barnes, 2010). Thus, the Commission

\footnotetext{
In general, it was the particular provisions of the Maastricht TEU that gave new impetus for the recognition of political rights through the political integration of the Union (TEU, Arts. 8-8e referring to the Citizenship of the Union). However, despite the European Council's newly provided EU accession criteria in 1993 and 1995, the 'enlargement article' in the subsequent 1997 Amsterdam TEU nor further amended Nice TEU did not include reference to them. Nevertheless, Amsterdam TEU provided an additional criterion only in the field of political criteria, i.e. that the applicant European State needs to "respect the principles set out in Article 6(1) TEU" (TEU, Art. 49), and inter alia gave the authority to the European Court of Justice in this field. This Article has substantially expanded in Lisbon TEU (Article 2) and is now much more all-inclusive, stating: "The Union is founded on the values of respect for human dignity, freedom, democracy, equality, the rule of law and respect for human rights, including the rights of persons belonging to minorities. These values are common to the Member States in a society in which pluralism, non-discrimination, tolerance, justice, solidarity and equality between women and men prevail." It was only in the Lisbon TEU that reference to European Council conclusions has been included in the Art. 49. Additionally, the European Union Charter of Fundamental Rights was included as an EU-originating legal framework on human rights provisions complementing the previously existing Council of Europe based European Convention on Human Rights and Fundamental Freedoms.
} 
initially sets the political criteria before the accession negotiations start and during them interprets the candidate's progress in meeting the criteria. Member states however decide to what extent they will take the EC's proposals into consideration as recently confirmed by Lovec (2012) in his analysis of the EU enlargements of 2004 and 2007. Furthermore, other international institutions have been included as relevant in achieving the fulfilment of some of the conditions for EU membership in the case of South East Europe/Western Balkan states, e.g. the Council of Europe in the case of respect for minorities, the International Criminal Tribunal for the Former Yugoslavia (ICTY) in terms of post-conflict resolution, UNHCR in terms of citizenship issues and return of refugees and Stability Pact for South Eastern Europe and its successor Regional Cooperation Council with respect to regional post-conflict cooperation and reconciliation. In this context, we conduct a holistic discussion on the formation of content of conditions for EU accession taking into account the above listed international actors.

A second aim of the article is to address an important research gap in terms of analysing the application of political criteria and political conditionality in the EU accession process. It is characteristic of the criteria related to democracy and the rule of law that they are very difficult to measure objectively (Beurdeley, 2003). For example, some of the EU's principles related to political criteria are inexistent in EU primary legislation (e.g. minority protection) or have only been formulated recently and have been changing due to new phenomena in the international environment. Hence, the ambiguity in setting, interpreting and measuring political criteria provides apt opportunity for the EU to perform its most successful external action strategy, i.e. political conditionality, which lays exactly in the interpretation of the compliance with political accession criteria. For example, the EC's negative assessment of progress in 1998 temporarily removed Slovakia from the list of first-wave countries in the Big Bang enlargement, and Turkey's failure to fulfil the political criteria has been a serious obstacle to the opening and the continuation of negotiations since 2010. Moreover, cases of additional political conditions, such as constitutional reform for Bosnia and Herzegovina, respecting agreements reached with Kosovo for Serbia or agreeing with neighbouring countries on the use of the state's name for Macedonia, confirm that political conditionality essentially demands adequate fulfilment by the applicant. This indicates that serious violation of political accession criteria or additional 
conditions can lead to negative conditionality and according to Pridham (2005, p. 56) even to the termination of negotiations. Nevertheless, it is quite surprising that there is a lack of comprehensive analysis on this topic (for exceptions see: Schimmelfennig and Schwellnus, 2006; Pridham, 2005; Mehikić and Šabič, 2008; Noutcheva, 2012). This research aims to investigate on the one side the application of political EU accession criteria for applicant states in terms of substance and procedure, and on the other side the interpretation of the (in)adequate compliance with these standards and the setting of additional conditions in form of political conditionality.

\section{Methodology}

The method chosen to achieve the above aims is a comparative analysis of the application of political accession criteria and the use of political conditionality in the EU accession processes of Slovenia and Croatia. We expose cases in which political conditions represented big challenges, even brought the candidate states to be faced with negative conditionality and demanded long-term efforts to be successfully undertaken. The two states both gained independence by breaking away from the Socialist Federative Republic of Yugoslavia and thus had a similar historical institutional (legal, political, economic and administrative) organization. However, they went through the accession process under different circumstances. Slovenia, as one of the ten Big Bang enlargement states, aimed for EU membership immediately after declaring independence and even before gaining international recognition in 1992 (Bojinović Fenko and Požgan, 2014, p. 58). It was a part of a large group of candidate states (12) during a very favourable domestic and international climate regarding the enlargement. Croatia, on the other hand, set itself on the EU accession path no earlier than in 2000 due to the preceding independence war (1991-95) and isolationist foreign policy towards the EU under Tuđman's reign (Jović, 2006; Šeperić, 2011 ). ${ }^{2}$ Moreover, Croatia faced additional demands stemming from international regional post-

2 For a comprehensive overview of the Croatian foreign policy path from the break-up of Yugoslavia to the entrance in to the EU, see Šelo Šabić (2014). 
conflict resolution and reconciliation programs for South-Eastern Europe/ Western Balkans (see more on this below) as its negotiation process was set within the Stabilization and Association process. Finally, the so called enlargement fatigue hit EU institutions and member states, especially after the disappointment with the Constitutional Treaty failure in 2005, just a few months before the start of Croatian negotiations (Brozina 2012). In this respect, the two states are comparable in terms of domestic institutional environment for incorporating political accession criteria but they stood at different starting points due to their pre-application history, which potentially bears relevance for the application of additional political conditionality.

We expect to confirm the following hypothesis: The Commission and the European Council applied political accession criteria and political conditionality towards Croatia more extensively and meticulously than towards Slovenia due to a different assessment of the two states' starting points in the process of accession negotiations and a difference in the two states' performance in meeting the political and additional criteria. The sources of data for the comparative analysis are the Commission's initial assessments and Progress Reports on Slovenian and Croatian negotiation processes and the relevant European Council Presidency Conclusions during the time span from the beginning of accession negotiations to the end of the respective negotiations and the signing of accession treaties; for Slovenia from June 1996 until April 2003 (6 years and 9 months) for Croatia from October 2005 until December 2011 (6 years and 2 months). Apart from the qualitative comparative analysis (the substance of conditions) and quantitative comparative analysis (the frequency of referring to conditions), ${ }^{3}$ we also draw from a small number of semistructured interviews with Slovenian and Croatian state representatives involved in the respective negotiation processes.

\section{The substance of political accession criteria and the application of political conditionality}

In the project of joining the EU, all the conditions for CEECs were primarily about the rule of law, democracy and human rights (Bučar and Brinar, 2002). The importance of democracy was underlined on numerous 
occasions, in the opinions of the institutions, and in numerous declarations of the Council, Commission and the European Parliament as well as in the jurisprudence of the European Court of Justice (Kochenov, 2004, p. 10). As Kochenov notes, the term 'rule of law' in the TEU refers to different national concepts and outlines the necessary level of accomplishment of the national reform demanded from candidate countries in order to become members of the EU. Noutcheva $(2012$, p. 45) explains that EU conditionality stemming from the Copenhagen criteria targets one aspect of the candidate's sovereignty, i.e. 'control', defined as the "capacity of a state to govern the internal and external public affairs /.../ efficiently /.../." The EU's concern, addressed through pre-accession packages, is thus not to accept weak or potentially failing states. This was confirmed by the Commission itself in its 2012-13 EU enlargement strategy, stating that "/s/trengthening the rule of law and democratic governance is central to the enlargement process" (European Commission, 2012, p. 2). The Council Decision on Slovenia in January 2002, for example, already outlined five main areas of scrutiny related to the assessment of the 'democracy' and 'rule of law' criteria (Kochenov 2004, p. 13): elections, the functioning of the legislature, the functioning of the executive, the functioning of the judiciary and anti-corruption measures.

The respect for human rights and minority protection were set in the EU's enlargement strategy for CEECs to prevent social exclusion and discrimination in post-communist societies. Despite the fact that it is one of the founding principles of the EU, there is a lack of acquis communautaire concerning protection of minority rights. Since the EU has not developed any minority standard to be applied to existing member states so far, there is a discrepancy between the internal and external application of the minority norm by the EU (Schwellnus, 2006, p. 187). Non-discrimination is generally required as part of the EU acquis, but it is also specifically demanded to address minority problems in certain applicant countries, in particular with regard to the Roma population in CEECs (Schwellnus, 2006, p. 195). Meeting the minority protection criterion especially pertains to the Slovenian and Croatian EU accession processes.

Political conditionality is regarded as a successful strategy of the EU enlargement policy applied since the 2004 enlargement accession process (Kochenov, 2004). By making a highly attractive external incentive 
- the benefits stemming from membership - conditional on democracy, human rights, and peaceful conflict management, the EU has induced its wouldbe members to conform to these political norms (Schimmelfennig, 2008). Political conditionality ties a specific reward to fulfilment of defined conditions and is closely linked to the EU's self-definition as a normative actor (DeBardeleben, 2008). Thus, political conditionality is a method used by the EU that promotes political norms and consists of positive and negative actions. The carrot and stick method works best when exercised in the advancement of membership and has to be credible in two ways: it has to target countries' need to be certain that they are rewarded with significant steps towards accession (soon) after complying with the EU's political conditions, and that they will otherwise be excluded from EU membership (Schimmelfennig, 2008, p. 920). In this study, we focus on the negative actions applied on the two countries, using the notion 'negative conditionality' as a pattern of conditionality application when candidate countries fail to meet the criteria - they are consequently denied assistance, association or membership, and are left behind in the competition (Schimmelfennig and Sedelmeier, 2005, p. 5).

Since 1997, the Commission has regularly evaluated the political conditions in all candidate countries, exerting diplomatic pressure on them by means of annual opinions and Progress Reports. The Commission's approach to the political conditions has evolved considerably - over time it became more precise, prompted by the need to improve the analysis of the extent to which political requirements are met, which led to criticism of the first regular reports in 1998 (Pridham, 2005, p. 41). The lack of clear methodology for objective cross-national comparisons between applicant states and ambiguity in the annual regular reports have contributed to a view that the EU was demanding higher political conditions of candidate countries when compared to member states (Pridham, 2005, p. 41). Furthermore, this phenomenon can be problematic due to the EC's post-2004 application of the principle of 'differentiation', meaning that each applicant country progresses at its own pace according to its level of preparedness for accession; the Commission $(2012$, p. 3) also refers to it as the 'principle of own merits'.

The exercising of political conditionally by EU member states has been called 'a different kind of two-level game' (Šabič, 2002), referring to the 
experience of CEECs in the Big Bang enlargement, e.g. When Slovenia had to face the leverage of Austria and Italy and concede to their bilateral conditions in exchange for their support for its EU accession. Bilateral political conditionality has been present in enlargement process since its beginnings (e.g. French opposition to British accession in the 1960s). But as this analysis will show, additional political conditions may not only originate from the interpretation of Article 49 of the TEU but can derive from an opportunity especially for EU member states to turn their important unresolved bilateral issues with the applicant state into accession conditions with only a vague or no reference to the EU acquis.

\section{Comparative analysis of the application of political accession criteria to Slovenia and Croatia}

The discussion in this section aims at elaborating the Commission's opinion on the Slovenian and Croatian applications for EU membership (European Commission, 1997; 2004), and analyzing all the Commission's Progress Reports on the two states through quantitative and qualitative analysis, deriving from the above conceptualization of political criteria and their interpretation through political conditionality. The results are then compared in Table 1. From the Commission's initial opinion, it is very indicative that the subdivision Minority rights, protection of minorities and refugees in the opinion on Croatia (European Commission, 2004, p. 24) was analyzed more extensively compared to the opinion on Slovenia (European Commission, 1997, p. 20); the former spanning five pages and the latter only three paragraphs. Turning to the qualitative analysis of the two respective opinions, additional issues considering minorities are analyzed only in the opinion on Croatia: culture, educational institutions, the Ombudsman's role, the representation in state administrative and judicial bodies, minority representation in parliamentary elections and in the state administrative and judicial bodies, their representation in the media, and the number of cases pending in the European Court for Human Rights against Croatia (European Commission, 2004, pp. 24-9). In comparison, in its Progress Report on Slovenia in 1998 (p. 11), the Commission did address the issue of human rights breaches in Slovenia in the infamous case of 'Erased' (izbrisani) ${ }^{4}$ under the title "Civil and Political Rights" referring to

4 The case deals with about 26.000 inhabitants of Slovenia mainly originating from the former Yugoslav republics, who, after Slovenian independence, did not opt for Slovenian citizenship and whose names were thus erased from the register of permanent residents. 
the UNHCR estimation that about 5.000 to 10.000 people are in question, stating that: "There has been an increasing commitment to solve the issue by a special law aiming at regulating the position of the persons concerned." A year later, the EC withheld from further pressure on this issue after a Law on regulation of the status of citizens of other Successor States of the former Yugoslavia in Slovenia was adopted in July 1999 (Pistotnik 2010, p. 72) by stating that "Slovenia has addressed the problem of former Yugoslav citizens without regulated status /.../" (European Commission, 1999, p. 16), despite the fact that the issue remained unresolved until 2012 when the European Court of Human Rights ruled in favour of a group of the Erased, deciding that the Slovenian government is obliged to pay damages to each of the prejudiced individuals. Another essential difference in the starting positions of the two states is the fact that Chapter 23 (Judiciary and Fundamental Rights) did not exist in Slovenia's negotiations, while it was substantial and decisive for Croatia, including a new methodology of setting up benchmarks in four areas: (1) judiciary; (2) fight against corruption and organised crime; (3) fundamental rights and (4) ICTY co-operation. Most of the ten benchmarks in chapter 23 were divided into sub-benchmarks which focused on the implementation of measures and the establishment of track records, whereby data for EC's interpretation was gathered by the Commission itself from Croatian authorities, peer-assessment missions staffed by EU member states and from various international and non-governmental organisations (European Commission 2011, p. 2). Pusić (2012) and Drobnjak (2012) explained that in comparison to the 2004 and 2007 enlargements a newly formed set of benchmarks in accession negotiations with Croatia are one of the main novelties in assessing compliance with accession conditions.

Table 1 further illustrates the Commission's application of political criteria in the Progress Reports: all the areas that the EC addressed were at least twice as detailed in the case of Croatia as they were in the case of Slovenia. It is evident that in the case of Croatia the Commission used the term 'political criteria' 60 times in the period from 2005 to 2011 , whereas in the case of Slovenia the phrase was used only 41 times during the same time span of six years (1997-2003), which is a 32 per cent lower frequency of reference. ${ }^{5}$ The highest difference appears in the first two years of accession negotiations

5 Each year one Progress Report is issued, thus seven of them have been analysed for both states. The number under the column 'reference' indicates the number of times the term 'political criteria' is counted within the Progress Reports' 
when 'political criteria' are mentioned four times (both years) for Slovenia and 12 and 10 times per year respectively (22 altogether) for Croatia.

Table 1: Analysis of the Commission's Progress Reports on Slovenia and Croatia - frequency of reference to political criteria

\begin{tabular}{|c|c|c|c|}
\hline \multicolumn{2}{|c|}{ SLOVENIA } & \multicolumn{2}{c|}{ CROATIA } \\
\hline year & reference & year & reference \\
\hline 1997 & 4 & 2005 & 12 \\
\hline 1998 & 4 & 2006 & 10 \\
\hline 1999 & 5 & 2007 & 7 \\
\hline 2000 & 9 & 2008 & 9 \\
\hline 2001 & 10 & 2009 & 8 \\
\hline 2002 & 9 & 2010 & 7 \\
\hline 2003 & 0 & 2011 & 7 \\
\hline TOTAL & $\mathbf{4 1}$ & TOTAL & $\mathbf{6 0}$ \\
\hline
\end{tabular}

Source: Authors' Survey.

Given that respect for minorities as a political criterion is particularly important to the analyzed research problem, we compare the frequency of use for the term 'minority/ies' in the two respective Reports. As shown in Table $2,{ }^{6}$ the difference in frequency of reference to this political criterion between the two countries is even more explicit; the Commission's Progress Reports on Croatia mentioned the topic of minorities 356 times which is more than 300 per cent of the frequency in its Progress Reports on Slovenia (111 times). This can of course be explained by the difference in the de facto situation in practice as regards the respect of minorities in the two states, since the standard of minority protection in Slovenia has been viewed positively (Bučar, 1999, p. 342; see also argumentation below), whereas Croatia had trouble meeting the minority rights demands due to its "preoccupation with nation" and contested process of building a sovereign nation-state until the late 1990s (Boduszyński, 2013, pp. 45-6).

6 Each year one Progress Report is issued, thus seven of them have been analysed in cases of both states. The number under the column 'reference' indicates the number of times the term 'minority/ies' is counted within the Progress Reports' texts. 
Table 2: Analysis of the Commission's Progress Reports on Slovenia and Croatia - frequency of reference to minorities

\begin{tabular}{|c|c|c|c|}
\hline \multicolumn{2}{|c|}{ SLOVENIA } & \multicolumn{2}{c|}{ CROATIA } \\
\hline year & reference & year & reference \\
\hline 1997 & 23 & 2005 & 86 \\
\hline 1998 & 14 & 2006 & 46 \\
\hline 1999 & 8 & 2007 & 36 \\
\hline 2000 & 9 & 2008 & 39 \\
\hline 2001 & 24 & 2009 & 50 \\
\hline 2002 & 33 & 2010 & 51 \\
\hline 2003 & 0 & 2011 & 48 \\
\hline TOTAL & 111 & TOTAL & 356 \\
\hline
\end{tabular}

Source: Authors' Survey.

In order to analyze the substance of political conditionality, we compare the content of the penultimate Progress Reports for the target countries. In its Progress Report on Slovenia one year before the closure of negotiations (European Commission, 2002), the EC listed only few areas related to political criteria where Slovenia needed more significant progress. Concern was expressed about court backlogs, about the integration of recognized refugees into society, and about the protection of civil and political rights.? Further progress was expected but this was not conditioned on Slovenia's entry into the EU. In the last Progress Report before Croatia's closure of negotiations (European Commission, 2010), the EC stated that Croatia had made good progress in the judiciary and fundamental rights, but enumerated the following nine areas - in reference to political criteria alone - where further progress was needed: judicial reform; protection of fundamental rights, especially minorities and refugees; infrastructure and equipment of courts; impunity for war crimes; implementation of anti corruption sector issues; political accountability for corruption; public spending; enforcement of human rights. ${ }^{8}$

7 "No reduction in court backlogs was achieved last year, despite the measures introduced by the Government. Although the number of pending court cases decreased slightly, the number of backlog cases has further increased" (European Commission, 2002, p. 22). "/T/he integration of recognised refugees into society should be improved. /.../ Additional steps have been taken to further improve the protection of civil and political rights, but some issues continue to merit attention" (European Commission, 2002, p. 25).

8 Judicial reform remains a major undertaking and significant challenges remain, especially relating to judicial efficiency, independence and accountability. Protection of fundamental rights has been strengthened but needs to be improved in practice, especially for minorities and refugees. Attention needs to be paid to integrating persons granted protection in Croatia and to protecting minors among irregular migrants. The infrastructure and equipment of courts, including case management systems, remains underdeveloped. Impunity for war crimes remains a problem. Further coordination and pro-active follow-up to the implementation of anti corruption sector issues are needed. A culture of political accountability for the corruption cases which are coming to light is lacking; preventive measures such as improved transparency in public spending need to be strengthened. Enforcement of human rights continues to be compromised by the persisting shortcomings in administration of justice, especially the length of proceedings 
The EC assessed in its Interim report on Chapter 23 three months before the closure of negotiations that "further work remains to be done, in particular to establish convincing track-records in the field of the judiciary and the fight against corruption, to address impunity for war crimes and to settle the outstanding refugee return issues" and thus it "will continue to monitor Croatia's progress closely and to further support Croatia /.../ to enable it to meet the benchmarks in this chapter" (European Commission 2011 , p. 7). Brozina (2012) explains that this in practice meant that the EC estimated that the time Croatia needed to implement above issues amounted to approximately 18 months - the duration of the ratification procedure. EU member states thus agreed on the EC proposal to close the negotiations and sign the Accession Treaty but have added to the European Council's December 2011 conclusions this new form of monitoring mechanism during the ratification process with a possibility of using sanctions (see more below).

With reference to the political accession criteria applied in the European Council Conclusions, we compare the frequency of the mentioning of the two countries individually and the contexts (positive/negative) in which references were made. Again, in the time spans from 1996 to 2003 for Slovenia and from 2004 to 2011 for Croatia, analysis shows that 'Croatia' was mentioned 12 times, and 'Slovenia' 14 times in the respective documents. Although there is no major difference in the figures themselves, the content of the Presidency Conclusions was more extensive in the case of Croatia than in the case of countries in the 2004 enlargement, and the context in which Croatia was mentioned is also quite different. Table 3 below illustrates that the European Council used negative political conditionality four times in the case of Croatia and not once in Slovenia's. The ratio between positive context references for the two countries is also significant: eight in the case of Slovenia and only two in the case of Croatia. 
Table 3: Analysis of the European Council Conclusions' references to Slovenia and Croatia

\begin{tabular}{|c|c|c|c|c|c|c|c|c|c|}
\hline \multicolumn{5}{|c|}{ SLOVENIA } & \multicolumn{5}{|c|}{ CROATIA } \\
\hline year & reference & $x$ & $Y$ & Z & year & reference & $x$ & $Y$ & Z \\
\hline 1997 & 1 & 0 & 0 & 1 & 2005 & 0 & 0 & 0 & 0 \\
\hline 1998 & 1 & 0 & 1 & 0 & 2006 & 5 & 0 & 0 & 5 \\
\hline 1999 & 2 & 0 & 2 & 0 & 2007 & 0 & 0 & 0 & 0 \\
\hline 2000 & 3 & 0 & 2 & 1 & 2008 & 0 & 0 & 0 & 0 \\
\hline 2001 & 1 & 0 & 0 & 1 & 2009 & 0 & 0 & 0 & 0 \\
\hline 2002 & 4 & 0 & 3 & 1 & 2010 & 0 & 0 & 0 & 0 \\
\hline 2003 & 1 & 0 & 0 & 1 & 2011 & 7 & 4 & 2 & 1 \\
\hline TOTAL & 13 & 0 & 8 & 5 & TOTAL & 12 & 4 & 2 & 6 \\
\hline
\end{tabular}

' $X$ ' refers to negative conditionality

' $Y$ ' refers to mentioning in a positive context

' $Z$ ' refers to neutral mentioning

Source: Authors' Survey.

A content analysis of the European Council Conclusions shows that, in reference to Croatia, expressions such as "further reforms needed", "full cooperation with the ICTY" and "take necessary steps" were used four times, while none for Slovenia. In the European Council Conclusions (201 1, p. 12), negative conditionality for Croatia is expressed. Along with the explanation that the "ongoing examination is being conducted in full respect of strict conditionality and in line with the negotiating framework", the European Council (2011, p. 12) on the basis of a proposal by the Commission refers to monitoring up to accession as a "necessary assurance to Croatia and current member states" and concludes the paragraph with a warning that it may otherwise, "acting by qualified majority on a proposal from the Commission, take all appropriate measures", meaning also to put a hold on the accession process. The same provision is included in the Croatian Accession Treaty to the EU (Title IV, Art. 36, point 1, Paral and point 2).

Based on the above analysis, we can confirm a part of the hypothesis stating that the European Commission and the European Council implemented political accession criteria more meticulously in the case of Croatia than in Slovenia's. This is backed by the following evidence: the difference in the Commission's initial assessments of the two applicant states, the frequency of reference to political criteria and minority/ies in 
the Commission's Progress Reports, the Commission's (non)persistence in monitoring the case of the 'erased' in Slovenia vs. a design of a special negotiation chapter for Croatia on Judiciary and Fundamental Rights, the difference in thoroughness of the EC's final remarks on the political criteria before the states' accession, the invention of benchmarks and track-record to assess Croatian implementation of accession criteria, the European Council Conclusions exposing political criteria for Croatia more often and with negative conditionality compared to Slovenia and finally, the invention of the monitoring mechanism during the ratification process with a possibility of withholding entry.

The data presented above show that the mode of interpretation and application of political accession criteria in the cases of Slovenia and Croatia were quite different. Viewed only from this perspective, a number of the EC's Progress Reports caused criticism in Croatia, echoed by the Croatian general public and politicians. Kolinda Grabar-Kitarović, a former Croatian Minister of Foreign Affairs and the current President of the Republic, stated for the Croatian leading daily newspaper (Jutarnji list, 2007) that "/t/he EU is most restrictive towards Croatia. The criteria may be the same but the implementation is tightened and more intense. Formalized, rigorous, detailed and comprehensive standards during the negotiations are the rule, not an exception." During a visit to the German Chancellor Angela Merkel, Croatian Prime Minister Zoran Milanović stated that Croatia's path to the EU was difficult, "perhaps the most difficult of all the countries so far" (Jutarnji list, 2012). The comparative analysis below investigates potential sources of these particularities of the Croatian negotiation process, in relation to previous enlargements, and most directly to the case of Slovenia.

\section{Comparative analysis of the application of political conditionality towards Slovenia and Croatia}

An analysis of the political conditionality exercised by the Commission and EU member states within the (European) Council illustrates the nature of political conditionality in the EU accession process. It is not necessary here to examine details of bilateral disputes or deeper motivations of member states. However, we do identify whether the condition set by the EC or a member state to a candidate state is related to the EU acquis 
(Table 4, in white boxes) or it refers to other issues, mainly deriving from the interpretation of political criteria for membership or member states' bilateral demands from a candidate state (Table 4, in grey boxes).

According to our thesis, if cases of EU acquis-related additional conditions for Croatia prevail, the above established differentiation in applying political conditions more frequently and meticulously to Croatia can be attributed to the difference of the two states' starting points in the accession negotiations and their different pace of progress, Croatia's initial assessment being more difficult because of its post-conflict domestic conditions and regional demands for cooperation and reconciliation. On the other hand, we presume that should cases of extra-acquis political conditionality prevail in the case of Croatia, this would lead to a conclusion that Croatia's EU accession path was affected by causes not pertaining exclusively to the country's own political will and performance in the accession process. The political conditionality applied to Slovenia and Croatia (left and right column respectively) during their accession processes is summarized in Table 4. Individual rows present the political conditions as interpretations of political criteria or other conditions set by member states in the (European) Council and by the Commission.

Slovenia faced three bilateral demands posed by both its neighbouring EU members, Italy and Austria. The border issue with Italy was not problematic as such but it was historically related to other issues Italy raised against Slovenia in the European Council. The Treaty of Osimo of 1975, settling the former Yugoslavia's (now Slovenia's) western border with Italy was successfully defended by Slovenia as part of the European post-World War system, which, if put in question in the case of Slovenia, would lead to questioning the entire post-1945 European reordering (Bučar, 1999, p. 343). Italy also claimed poor protection of its minority in Slovenia but was again unsuccessful. It had been stated on several occasions by the Council of Europe's experts that the standard of minority rights for Italians living in Slovenia could in fact be taken as a role model in Europe (Bučar, 1999, p. 342). The status of Italians who left Istria after the Second World War was problematic in terms of compensation for the property expropriated by Yugoslavia, which Slovenia was handling by financial remuneration as a successor to the 1983 Treaty of Rome. For Slovenia to prove its Europeanness, Italy demanded the right of the first 
offer for ex-Italian property on Slovenian territory. In the eyes of the Italian government, this would be a 'European' answer to alleged injustices against the Italian population in post-war Istria (Bučar, 1999, pp. 344-5). The second condition was that Slovenia liberalize its real estate market even before signing the Europe Agreement since the Slovenian legislation at the time did not allow the acquisition of land by foreigners. In doing so, the Berlusconi government succeeded in transferring a bilateral problem to the European level and blocked any progress in signing the Europe Agreement with Slovenia (Šabič, 2002). When the Prodi government came to power in May 1996, Slovenia agreed to change its Constitution but retained a clause by which preferential access to the Slovenian real estate market will be granted to people living in Slovenia for more than three years - the so called Spanish compromise, mediated by the Spanish EU presidency. Italy then signed the Europe Agreement.

Closure of the Krško nuclear power plant was a condition made by Austria in 2000, based on its safety concerns about the complex. A study costing over 700,000 EUR financed by the PHARE programme was launched as the Austrian government made it clear that it would not join the consensus of EU members on closing Chapter 14 (Energy) for Slovenia as long as the results of this study were not known. Austria had the support of some other EU member states (Italy and Greece) in making this point and the Commission (2001, p. 9) included the condition in its proposal for the December 2001 Council Decision. As the analysis showed that there were no active tectonic joints in the Krško area, Austria gave the green light in return for a set of new measures introduced by Slovenia to monitor the safety of the nuclear power plant. Slovenia found it hard to recognize another Austrian demand - minority protection of the Germanspeaking community, since the German-speaking population in Slovenia was not only relatively small in terms of numbers, but its members lived scattered around the country. Austria insisted on using a precise term for the German-speaking population in Slovenia, namely the Germanspeaking Volksgruppe (ethnic group) (Šabič, 2002, p. 110). Following pressures from the Austrian government, Slovenia agreed to the proposal of the so-called Cultural Agreement (signed on 30 April 2001) and Austria accepted that German Volksgruppe are not entitled to protection under Article 64 of the Slovenian Constitution, which refers to the Italian and Hungarian national minorities in Slovenia (Šabič, 2002, p. 110), but rather 
to protection under Article 61 referring to the right of expressing national affiliation. Additionally, Austria took issue with Slovenia's succession to one of the decrees adopted by Yugoslavia in November 1944, stipulating inter alia the nationalisation of all property of persons of German nationality, with the exception of those who fought in the Allied Forces or were neutral in the Second World War. Slovenia was of the opinion that denationalization, an ongoing process in Slovenia at the time, should not include restitution of property to Germans (Austrians). Austria decided on a double-track approach (Šabič, 2002, p. 112). On the one hand, it was careful enough not to dispute the decree head on, given that such decrees could have been perceived by other EU members apart from Slovenia as being embedded in the current European order (as referred above, Italy had been previously unsuccessful in this regard). On the other hand, Austria shared its views about the possibly discriminatory practices of the Slovenian denationalization law with other EU members. In September 1999, the Commission effectively echoed the Austrian interests as it included denationalization on the agenda of accession negotiations with Slovenia, deciding that denationalization was not a subject of negotiations, but any proof of discrimination was, due to the general principle of non-discrimination applied in the EU (Šabič, 2002, pp. 112-13).

Slovenia closed the Europe Agreement on 10 June 1996 and at the same time applied for EU membership; the accession negotiations began in April 1998. In the meantime, direct pressure was exerted by the European Commission on the Slovenian political leaders to abandon its 'away from the Balkans' foreign policy and reintegrate into the Southeast European (SEE) post-conflict initiatives as a condition to start accession negotiations with the EU (and NATO). The Slovenian government succumbed to this pressure in the light of the 'golden carrot' effect, however it also managed to successfully make its identity-based role conditional on assuming only the position of a donor state (and not an aid-recipient as other states of the EU-sponsored Stability Pact for SEE and the US-sponsored SEE Cooperation Initiative) (Bojinović Fenko and Požgan 2014, p. 62-3). 
Table 4: Comparison of political conditionality by the Commission and by the EU member states in the EU accession process of Slovenia and Croatia

\begin{tabular}{|c|c|c|c|}
\hline \multicolumn{2}{|l|}{ SLOVENIA } & \multicolumn{2}{|l|}{ CROATIA } \\
\hline $\begin{array}{l}\text { member states in } \\
\text { the (European) } \\
\text { Council }\end{array}$ & $\begin{array}{l}\text { European } \\
\text { Commission }\end{array}$ & $\begin{array}{l}\text { member states in the } \\
\text { (European) Council }\end{array}$ & $\begin{array}{l}\text { European } \\
\text { Commission }\end{array}$ \\
\hline Italy: national border & $\begin{array}{l}\text { Regional } \\
\text { cooperation in } \\
\text { SEE (Stability } \\
\text { pact for SEE } \\
\text { and SECI) }\end{array}$ & $\begin{array}{l}\text { Italy and Slovenia: } \\
\text { withdrawal from } \\
\text { Ecological-Fishing } \\
\text { Protection zone in the } \\
\text { Adriatic Sea }\end{array}$ & $\begin{array}{l}\text { negotiation Chapter } \\
\text { 23: Justice and } \\
\text { fundamental rights, } \\
\text { including: } \\
\text { judiciary }\end{array}$ \\
\hline $\begin{array}{l}\text { Italy: status of Italian } \\
\text { minority }\end{array}$ & & $\begin{array}{l}\text { Slovenia: peaceful } \\
\text { settlement of the } \\
\text { national border on } \\
\text { land and on the sea }\end{array}$ & $\begin{array}{l}\text { fight against } \\
\text { corruption and } \\
\text { organized crime }\end{array}$ \\
\hline $\begin{array}{l}\text { Italy: real-estate } \\
\text { ownership status of } \\
\text { Italians }\end{array}$ & & $\begin{array}{l}\text { Slovenia: settlement } \\
\text { of the dispute over } \\
\text { Croatian deposits in } \\
\text { former Ljubljanska } \\
\text { Banka within the } \\
\text { framework of Yugoslav } \\
\text { succession process }\end{array}$ & $\begin{array}{l}\text { fundamental rights } \\
\text { (including minority } \\
\text { rights and return of } \\
\text { refugees) }\end{array}$ \\
\hline $\begin{array}{l}\text { Austria: nuclear } \\
\text { power plant Krško } \\
\text { (negotiation } \\
\text { Chapter 14: Energy) }\end{array}$ & & & $\begin{array}{l}\text { full cooperation with } \\
\text { the ICTY }\end{array}$ \\
\hline $\begin{array}{l}\text { Austria: } \\
\text { advancement of } \\
\text { status of German } \\
\text { speaking population } \\
\text { to national minority }\end{array}$ & & & $\begin{array}{l}\text { regional cooperation } \\
\text { in the Western } \\
\text { Balkans (Regional } \\
\text { Cooperation } \\
\text { Council) }\end{array}$ \\
\hline Austria and EC: dena & ionalization & & \\
\hline
\end{tabular}

white boxes: EU-acquis related conditionality

grey boxes: non EU-acquis related conditionality

Source: Authors' Survey.

The political conditionality imposed on Croatia by the Commission and by EU member states in the (European) Council is illustrated on the right side of Table 4. The most important conditions brought forward by the Commission were: the establishment of minority rights, the right of refugee return, cooperation with the ICTY and cooperation with the neighbouring states (Boduszyński, 2013, p. 46) with special attention on post-conflict reconciliation (Drobnjak, 2012); all related to Croatia's domestic and Western Balkans post-conflict situation. The Croatian civil society and political elite were extremely sensitive to some of these 
additional conditions, as mentioned above, due to their importance in the ongoing nation-building process. An example of the negative sentiment in Croatia in response to this additional conditionality were in 2005 objections to the extradition of war-crimes suspect Ante Gotovina, arguing that Croatia should not surrender and let go of those who had helped defend the country during the war (Roter and Bojinović, 2005, pp. 50-1). As for additional careful monitoring of corruption, good governance and democratization, the EC (2012, p. 2) itself stated that the importance of "an increased focus on the areas of /strengthening the rule of law and democratic governance/ and further improving the quality of the process" is highlighted by "/t/he lessons learnt from previous enlargements". Brozina (2012) assesses that the experience gained in 2004 and 2007 enlargements by the Commission was two-fold. First, the long-term negotiation with 12 candidate countries contributed to significant experience of the Directorate-General for Enlargement that afterwards focused only on one country. Second, both Brozina (2012) and Drobnjak (2012) agree that the "lessons learned from the post-accession non-implementation of political criteria in Bulgaria and Romania were essential in the case of Croatian negotiation process." Despite the fact that "the EU insisted on specific reforms in the most criticized sectors and policy areas of the Bulgarian political system" (Noutcheva, 2012, p. 143), namely the judiciary system, public administration, corruption and the treatment of the Roma minority, and that Bulgaria had shown substantial compliance, "important deficiencies in the quality of government remain even after EU accession" (Noutcheva, 2012, p. 157), 9 much extending the previous 2004 enlargement focus on mainly denationalization and minority issues (Brozina 2012). The Commission realised that the above exposed areas demand more than a passing of law and require a longer period for full implementation especially as the latter was not based on any negative sanctions (Ibid.). This was taken into consideration in the case of Croatian accession negotiations as shown above with the invention of the monitoring mechanism during ratification. Another source (Anonymous, 2012) observes that in the Big Bang accession processes candidates were compared more to the successful 1995 enlargement in economic than in political terms. Thus, only when they demonstrated poor performance in democratic governance after accession, the EC took this as an indicator to focus

9 Bulgaria is not an exception in this matter. For a study of 'democratic backsliding' in Hungary and Romania in 2012-13, see Sedelmeier (2014). 
more extensively on this area in the case of Croatia. Additional insight in this context is offered by Brozina (2012), stating that a larger number of countries in Big Bang accession negotiations meant that EU institutions were mainly focused on a small number of key states (Poland, Czech Republic and Hungary); as long as other candidates did not lag too much behind these three, the Commission had no reason to question their accession. In case of Croatia, no reference country existed.

Croatia first experienced political conditionality by EU member states based on the issue of a non-political criterion, i.e. its proclamation of the Ecological and Fisheries Protection Zone in the Adriatic in October 2003. This unilateral proclamation particularly upset Italy, for such a zone would significantly reduce the possibilities for Italian fishermen to fish in the Adriatic. For Slovenia, the zone was perceived as a possible precedent for the delineation of the sea border between Slovenia and Croatia, which was (still is) yet to be finalized (Roter and Bojinović, 2005, p. 452). Italy and Slovenia called for a 'European solution' (i.e. an agreement that would be acceptable to all, rather than a unilateral proclamation), and thus the Croatian Sabor amended in June 2004 its original decision "so that the proclamation of the zone was delayed for EU member states until the conclusion of a new partnership on fisheries agreement between Croatia and the EU" (Roter and Bojinović, 2005, p. 452).

The border dispute between Slovenia and Croatia nevertheless remained open and was being solved bilaterally by peaceful means. The states reached two agreements, signed by their respective Prime Ministers Drnovšek and Račan in 2001 and by Janša and Sanader in 2007, but both remained unratified. After Croatia included its border proposal in maps presented in the EU accession process without clearly marking the disputed status of the relevant sections of the borderline, these documents were perceived by Slovenia as a potential basis for prejudging a resolution of the two countries' border dispute (STA, 2008). Slovenia therefore blocked 13 of Croatia's negotiation chapters in its EU membership talks that included the contested documents. The states' prime ministers Kosor (Sanader's successor) and her Slovenian counterpart Pahor managed to agree upon and sign an Arbitration Agreement on the border dispute on 4 November 2009 in Stockholm, mediated by the Swedish prime minister, who held the EU presidency at the time. After the Slovenian people confirmed the 
Agreement in a referendum in June 2010, Slovenia lifted its blockade on Croatia's negotiation chapters. Another issue raised by Slovenia as a condition just before the ratification of the Croatian Accession Treaty was a solution of financial compensation for the Croatian depositors who lost their foreign currency savings in the liquidation of the Slovenia-based Yugoslav-era bank Ljubljanska banka. Slovenia insisted the issue should be settled as part of a broader Yugoslav succession ${ }^{10}$ deal to be brokered by the Bank of International Settlements in Basel, Switzerland (Rettman, 2012) rather than through individual civil lawsuits against the Slovenian state at Croatian courts." On 11 March 2013, the two governments signed a Memorandum of Understanding stating (para. 1) they "agree that the settlement for the transferred foreign currency savings of the Ljubljanska banka in Croatia will be found on the basis of the Agreement on Succession Issues" thus enabling Slovenia's ratification of the Croatian Accession Treaty. ${ }^{12}$

Based on the above analysis we have shown that for both states more cases of political conditionality were linked to issues not pertaining directly to the EU acquis than deriving from the demands for harmonization with EU law; five in case of Slovenia and seven in case of Croatia. There is however a two-fold difference in this result. First, all the additional conditions were posed to Slovenia before it signed the Association Agreement and started accession negotiations; none were additionally imposed on Slovenia during the negotiation process. Croatia, in turn, was faced with all the elements of political conditionality during the accession negotiations except for the demands to withdraw its Ecological and Fisheries protection Zone in the Adriatic in 2003 and to extradite ICTY war-crimes indictee Ante Gotovina in 2005. Second, the sources of additional conditionality in the case of Slovenia were the two neighbouring EU member states, Italy and Austria referring to denationalization and Yugoslav break-up related bilateral issues; the European Commission posed one condition related to Slovenian foreign policy engagement in the SEE post-conflict cooperation schemes. The latter could be interpreted as one of the experiences the EC built on in the case of Croatian accession negotiations, as the

10 For a full list and a discussion on Slovenian open issues with states of post-Yugoslav area, see Bojinović Fenko and Šabič (2014).

11 For more on the issue and its regional (post-Yugoslav) dimension, see Udovič (2011).

12 It is however relevant to note that this agreement is not being respected by Croatia, as civil lawsuits against Ljubljanska banka and Slovenia at Croatian courts continue after its EU accession. 
condition for all Western Balkans (potential) candidate states is regional cooperation and settling bilateral open issues within the Stability Pact for SEE's successor Regional Cooperation Council. ${ }^{13}$

In the case of Slovenia, the EC did not pursue the issue of human rights breaches of the Erased inhabitants of Slovenia which it could have easily turned into an element of political conditionality. However, the Commission did pay attention to Austria's claim relating to denationalization of realestate property for foreign citizens, which was eventually 'Europeanized' within the EU non-discrimination clause and represented the EC's second condition on Slovenia. On the other hand, five of Croatia's eight additional conditions derived from the Commission's initial assessment and further interpretation of Croatia's accession progress and three came from the country's neighbouring EU member states, Slovenia and Italy. We assess that the reason for the Commission to have taken up more initative in terms of interpretation of accession criteria is also linked to the learning process (as described above). Brozina (2012) estimates that since a simple majority of Commissioners' votes is enough to pass an EC Progress Report compared to a necessary unanimity of European Council members to pass its Conclusions, the process of monitoring Croatian accession has changed in favour of empowering the Commission. The latter received information on the candidate's implementation also by member states' embassies in Croatia and on this ground it was easier to propose compromise assessments and proposals in Progress Reports, later to be welcomed (or criticized) by member states. However, an important lesson learned from previous enlargements was that countries show poor implementation of political criteria once the accession Treaty is signed. Therefore, two new methods have been introduced for Croatia, namely benchmarks to assess progress during the negotiations and monitoring of the latter's implementation during the ratification process.

13 The areas of cooperation in the framework of this institution are: economic and social development; energy and infrastructure; justice and home affairs; security cooperation; building human capital, as well as cross-cutting issues such as parliamentary cooperation, media development, civil society activities and gender mainstreaming (Regional Cooperation Council 2014). 


\section{Conclusion}

This article aimed to identify differences in the application of political criteria and additional political conditionality in the substance and in the process of EU accession of Slovenia and Croatia. We confirmed that the two EU institutions, namely the Commission (in its initial Opinion on the two states' application for EU membership and in the relevant Progress Reports) and the European Council (in its Presidency Conclusions) did refer to fulfilling political conditions more frequently and also more meticulously in the case of Croatia than in the case of Slovenia. Apart from the difference in frequency, extent of details in referring to political criteria, and the use of negative conditionality, we also established the differences in content and procedure in the application of political conditionality towards the two states. For both countries more cases of political conditionality were linked to issues not pertaining directly to the EU acquis but derived from demands unconnected to harmonization with EU law. In case of Slovenia, these were open bilateral issues stemming from the break-up of Yugoslavia. In the case of Croatia, demands originating from the Stabilization and Association Process prevailed. As regards the procedural difference, all additional conditions were set for Slovenia early on, before the start of the negotiation process, while political conditionality was imposed on Croatia all along the accession process, even until the very end during the ratification process of its Accession Treaty. Additionally, the findings show that the Commission's additional conditions prevailed in the case of Croatia while EU member states' conditionality was predominant in the case of Slovenia. This points to a conclusion that during the Slovenian accession negotiations, the Commission acted as a relatively weaker institution, instructed by member states, while in the case of the Croatian accession negotiations, the EC had learned to act fully upon its powers, relied on a relatively easier internal decision-making procedure (rather than seek initial unanimity in the European Council) and predominantly posed accession conditions by itself.

Based on these three arguments, namely the prevailing extra-EU acquis conditions for Croatia, the application of political conditionality for Croatia during the accession and ratification process and mainly by the Commission, we conclude that, compared to Slovenia, Croatia's 
experience shows that political conditionality was not being posed only according to the country's initial assessment of preparedness for EU membership, its own merits and performance in the accession process. The EC expressed additional concerns about the political and administrative capacity-building of Croatia based on the experience from the 2004 and 2007 enlargements. During the almost seven-year period of Croatia's accession negotiations, the poor performance in rule of law and democratic governance in some of the new member states particularly raised concern in the EC regarding the EU's capacity to absorb weak states. Therefore, differences between Slovenia and Croatia in political conditionality derived not only from Croatia's difficult post-conflict domestic and regional context and the pace of its reforms, but also from the Commission's experience with previous enlargements, the institutional learning process, and the concern about the EU's absorption capacity. These circumstances led the Commission to apply political criteria for the Croatian accession more extensively and meticulously in comparison to Slovenia, and set additional conditions to ensure that Croatia would have built the necessary capacities to perform well as a member state before it entered the EU.

From a broader perspective, these findings indicate that, despite two Yugoslav succession-related conditions posed to Croatia by Slovenia, the fear of future Western Balkan enlargement being hijacked by bilateral post-Yugoslav political conditionality is not as founded as portrayed in political debates. This is confirmed by the results that in terms of procedure and content the application of political criteria and political conditionality in the case of Croatia, as the first Western Balkan state joining the EU, depended much more on the Commission than on member states individually. As the EC has now also learned from the Slovenian and Croatian enlargements, it may itself formulate additional accession conditions for further enlargements in the Western Balkans preventing potential open bilateral issues to be turned into EU political accession conditions. 


\section{B Bibliography}

Accession Treaty: Treaty concerning the accession of the Republic of Croatia, signed in Brussels on 9 December 2011, in force since 1 July 2013. Available at http://register.consilium.europa.eu/doc/ srv?|=EN\&f=ST\%2014409\%202011\%20INIT

Barnes, I. and Barnes, P., 2010. 'Enlargement'. In Cini M. and PerezSolorzano Borragan, N. (eds) European Union Politics, 3rd edn (Oxford: Oxford University Press), pp. 418-34.

Beurdeley, L., 2003. L'élargissement de l'Union européenne aux pays d'Europe centrale et orientale et auxîles du bassin méditerranéen, (Paris and Montréal: L'Harmattan).

Boduszyński, M. P., 2013. 'The Trials and Triumphs of Europeanization in Croatia: The Unbearable Weight of Structure and State-Building?' In Elbasani, A. (ed.) European Integration and Transformation in the Western Balkans; Europeanization or Business as Usual (Oxon and New York: Routledge), pp. 39-53.

Bojinović Fenko, A. and Požgan, J., 2014. Regionalisation of Slovenian foreign policy: escape from the Balkans, return to the Western Balkans. Studia Historica Slovenica 14 (1): 55-74.

Bojinović Fenko, A. and Šabič, Z., 2014. Continuity And Change In Slovenia's Foreign Policy: A Comparison To Yugoslavia And An Analysis Of The Post-Independence Period. In Keil, S. and Stahl, B (eds.) The Foreign Policies of Post-Yugoslav States; From Yugoslavia to Europe (Basingstoke: Palgrave Macmillan), pp. 47-67.

Bučar, B., 1999. 'The Issue of the Rule of Law in the EU Enlargement Process: Aspects of Slovenian-Italian Relations'. In Benedek, W., Isak, H. and Kicker, R. (eds) Development and Developing International and European Law: Essays in Honour of Konrad Ginther on the Occasion of his 65th Birthday (Frankfurt am Main, etc.: Peter Lang), pp. 339-53.

Bučar, B. and Brinar, I., 2002. 'Nekateri pre(po)misleki ob vstopanju v EU.' Teorija in praksa Vol. 39, No. 4, pp. 654-68. 
DeBardeleben, J., 2008. The Boundaries of EU Enlargement. Finding a place for neighbours, (New York: Palgrave Macmillan).

European Commission (1997) Agenda 2000 - Commission Opinion on Slovenia's Application for Membership of the European Union. Doc 97/19, 15 July.

European Commission (1998) Regular Report of the Commission on Slovenia's Progress towards accession.

European Commission (1999) Regular Report of the Commission on Slovenia's Progress towards accession. 13 October.

European Commission (2001) Proposal for a Council Decision on the principles, priorities, intermediate objectives and conditions contained in the Accession Partnership with Slovenia. COM(2001) 662 final, 13 November.

European Commission (2002) 2002 regular report on Slovenia's progress towards accession. COM(2002) 700 final, 9 October.

European Commission (2004) Communication from the Commission; Opinion on Croatia's Application for Membership of the European Union. COM(2004) 257 final, 20 April.

European Commission (2010) Commission staff working document. Croatia 2010 Progress Report. SEC(2010) 1326, 9 November.

European Commission (2011) Interim report from the Commission to the Council and the European Parliament on reforms in Croatia in the field of judiciary and fundamental rights (negotiation chapter 23), COM(2011) 110, 2 March.

European Commission (2012) Communication from the Commission to the European Parliament and the Council. Enlargement Strategy and Main Challenges 2012-2013. COM(2012) 600 final, 10 October.

European Council (1993) Conclusions of the Presidency, Copenhagen, 21-22 June.

European Council (1995) Conclusions of the Presidency, Madrid, 15-16 December.

European Council (2002) Conclusions of the Presidency, Copenhagen, 13 
December.

European Council (2011) Conclusions of the Presidency, Brussels, 9 December.

Jović, D., 2006. 'Croatia and the European Union; a long delayed journey.' Journal of Southern European and the Balkans, Vol. 8, No. 1, pp. 58-103.

Jutarnji list, 2007. Grabar Kitarović: EU najstroža prema Hrvatskoj. 4 October. Available at: http://www.jutarnji.hr/grabar-kitarovic--eunajstroza-prema-hrvatskoj/271008.

Jutarnji list, 2012. Milanović održao predavanje u Berlinu: 'Put Hrvatske k EU je najteži od svih zemalja dosad!' 19 September. Available at http://www.jutarnji.hr/milanovic-odrzao-predavanje-u-berlinu--put-hrvatske-k-eu-je-najtezi-od-svih-zemalja-dosad--/1054783/.

Kajnč, S., 2009. 'The Slovenian Presidency: Meeting Symbolic and Substantive Challenges.' JCMS 47, (Annual Review), pp. 89-98.

Kochenov, D., 2004. 'Behind the Copenhagen façade. The meaning and structure of the Copenhagen political criterion of democracy and the rule of law.' European Integration Online Papers, Vol. 8, No. 10.

Kochenov, D., 2005. 'EU Enlargement Law: History and Recent Developments: Treaty - Custom Concubinage?' European Integration Online Papers, Vol. 9, No. 6.

Pistotnik, S., 2010. Izbris kot poligon evropskih migracijskih politik ali "oprostite mi, prosim, ampak vaši predpisi so izbr isali moj status". In Kogovšek, N. and Petković B. (eds.) Brazgotine izbrisa; Prispevek h kritičnemu razumevanju izbrisa iz registra stalnega prebivalstva Republike Slovenije. (Ljubljana: Mirovni inštitut), pp. 53-77.

Lovec, M., 2012. 'The European Union is no Free Lunch: Reconsidering the Eastern Enlargement of the EU from an Intergovernmental Perspective.' Croatian International Relations Review, Vol. 17, No. 66, pp. 31-58.

Mehikić, M. and Šabič, Z., 2008. Načela pogojevanja v Evropski uniji, (Ljubljana: Fakulteta za družbene vede).

Memorandum of Understanding between the Government of the Republic 
of Slovenia and the Government of the Republic of Croatia, signed at Mokrice, 11 March 2013, in force since 14 March 2013.

Noutcheva, G., 2012. European Foreign Policy and the Challenges of Balkan Accession: Conditionality, legitimacy and compliance, (London and New York: Routledge).

Pridham, G., 2005. Designing Democracy - EU Enlargement and Regime Change in Post-Communist Europe, (New York: Palgrave Macmillan).

Regional Cooperation Council. 2014. Overview. Available at: http://www. rcc.int/pages/2/overview.

Rettman, A., 2012. Slovenia puts $€ 172 \mathrm{mn}$ price tag on Croatia's EU entry. EUObserver, 21 September. Available at: http://euobserver.com/ enlargement/117629.

Roter, P. and Bojinović, A., 2005. 'Croatia and the European Union: a troubled relationship'. Mediterranean Politics, Vol. 10, No. 3, pp. 447-54.

Schimmelfennig, F. and Sedelmeier, U., 2002. 'Theorizing EU enlargement: research focus, hypotheses, and the state of research'. Journal of European Public Policy, Vol. 9, No. 4, pp. 500-28.

Schimmelfennig, F. and Sedelmeier, U., 2005. 'Conclusions: The Impact of the EU on the Accession Countries.' In Schimmelfennig, F. and Sedelmeier, U. (eds) The Europeanization of Central and Eastern Europe, (Ithaca: Cornell University Press), pp. 210-28.

Schimmelfennig, F. and Schwellnus, G., 2006. 'Political Conditionality and Convergence: The EU's Impact on Democracy, Human Rights, and Minority Protection in Central and Eastern Europe.' Paper presented at the 5th Convention of the Central and East European International Studies Association, Tartu, 25-27 June.

Schwellnus, G., 2006. 'Double standards? Minority protection as a condition for membership.' In Sjursen, H. (ed.) Questioning EU enlargement Europe in search of identity, (New York: Routledge), pp. 186-202.

Sedelmeier, U., 2014. 'Anchoring Democracy from Above? The European Union and Democratic Backsliding in Hungary and Romania after Accession.' JCMS 52 (1): 105-21. 
STA, 2008. Slovenia Will Give Croatia the Red Light on Friday, PM Says (IV). Available at: http://www.sta.si/en/vest.php? s=a\&id=1347723.

Šabič, Z., 2002. 'Slovenia and the European Union: a different kind of twolevel game.' In: Linden, R. H. (ed.) Norms and Nannies: The Impact of International Organizations on the Central and East European States, (Lanham, MD: Rowman \& Littlefield), pp. 91-127.

Šelo Šabić, S., 2014. Croatia fast-forward Foreign Policy: From Yugoslavia to the EU. In Keil, S. and Stahl, B (eds.) The Foreign Policies of PostYugoslav States; From Yugoslavia to Europe (Basingstoke: Palgrave Macmillan), pp. 69-96.

Šeperić, M., 201 1. To Europe and Back - The Croatian EU Accession Process and Its Outcomes. SEER Journal for Labour and Social Affairs in Eastern Europe, No. 4, pp. 463-80.

Treaty on European Union as amended by the Treaty of Lisbon, signed in Lisbon on 13 December 2007, in force since 1 December 2009.

Udovič, B., 2011. 'The problem of hard-currency savings in Ljubljanska banka d. d., Ljubljana: between politics and (international) law.' Studia Historica Slovenica, Vol. 11, No. 1, pp. 185-213.

\section{Interviews:}

Anonymous, 2012. High diplomatic source at the Slovenian Ministry of Foreign Affairs. Email interview with one of the authors. 25 September.

Brozina, David, 2012. Undersecretary at the Permanent Representation of Slovenia at the EU, responsible for coordination of COREPER II and later national expert at the European Commission Directorate-General for Freedom, Security and Justice. Since 2011 he has acted as Minster Plenipotentiary at the Mission of Slovenia to Bosnia and Herzegovina. E-mail correspondence with one of the authors. 10 September.

Drobnjak, Vladimir, 2012. Chief negotiator on EU accession for Croatia and later Ambassador to the Croatian Mission to the EU. E-mail correspondence with one of the authors. 13 September.

Pusić, Vesna, 2012. Minister of Foreign Affairs of the Republic of Croatia. Email interview with one of the authors. 20 September. 
Ana Bojinović Fenko (ana.bojinovic@fdv.uni-lj.si) is Assistant Professor at the Faculty of Social Sciences, University of Ljubljana and Research Fellow at the Centre for International Relations at the same institution. She teaches courses in International Relations, European Studies and Diplomacy programmes. Her research interests are international regionalism (in the Mediterranean), foreign policy (of small states), and European Union external action, mainly interregionalism and enlargement policy. She is (co-)author of about 30 scientific articles and book chapters, (co-)author of four monographs and (co-)editor of three books. She coordinates the European Studies programme at her home institution and has been leading three European Union cofinanced projects "EU at school". She is an active participant at international conferences of associations such as ISA, EISA, CEEISA, IPSA and WISC and is the organizer of the 2016 CEEISA conference in Ljubljana.

Ana Urlić (ana.urlic@gmail.com) received her Master's Degree in Diplomacy at the Faculty of Social Sciences, University of Ljubljana, and B.A. in Economics at the University of Rijeka. During and after her studies she worked on various political campaigns as a member of Public Relations teams. For the last three years she worked as Senior Adviser at the Croatian Government, where she specialized in public relations and political campaigning. She is currently working as a Consultant at Madison Consulting in Zagreb, a company for strategic consulting and implementing public relations. Her areas of interest are political communication and public relations while the main focus of her academic research is International and European affairs, particularly the European Union and acceding Balkan countries. 